\title{
Nutritional potentialities of neem (Azadiracthaindica) plant parts as supplementary feed in ruminant production system
}

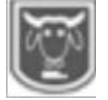

*Fasae, O. A., Aganto, T. O. and Jimoh, H.O.

Department of Animal Production and Health, Federal University of Agriculture, P.M.B.2240, Abeokuta, Nigeria.

Abstract

*Corresponding author: animalexp@yahoo.co.uk ;+2348036767665

This study was conducted to determine and compare the nutritional value of plant partsof neem as supplementary feedin ruminant production systems. Fresh matured leaves, seeds and bark of Neem (Azadirachta indica) were collected, air dried and analyzed for chemical and phytochemical constituents namely saponins, alkaloids, flavonoids and tannins as well as in vitro gas production and Dry matter digestibility. Results showed that the proximate and fibre fractions composition as well as the concentration of phytochemicals differed $(P<$ 0.05 ) across plant parts with a tolerable range of values that could supply critical nutrients needed to enhance ruminal microbial growth and fermentation. Crude protein contents were highest in leaves (19.76\%) with bark having the least values (7.20\%), while fibre fractions and phytochemical constituents were highest in bark with least values observed in seeds. Kinetics of gas production differed $(P<0.05)$ among plant parts with the leaves showing a shorter lag time and higher rate of fermentation. Gas production of neem plant parts increased $(P<0.05)$ with increasing incubation time, with the highest and the lowest values observed in the leaves and bark, respectively. In vitro Dry matter digestibility (IVDMD) differed $(P<0.05)$ within neem plant partsranging from 20.00 in bark to $28.00 \%$ in leaves. Methane $(\mathrm{mL} / 200 \mathrm{mg} D M)$ production also differed $(P<0.05)$ and ranged from 10.40 in bark to 26.00 in leaves, following the same trend as IVDMD. Neem plant partswere concluded to exhibit considerable potential that could be exploited as a good source of nutritional supplement in the diet of ruminants. This could help in alleviating the dry season feed shortages experienced by ruminants in most tropical countries.

Keywords: Neem, leaves, bark, stem, ruminant, chemical, phytochemical, in vitrodigestibility

\section{Introduction}

In the tropics, the bulk of the feed available to ruminant animals are cheaply sourced from the tree fodders and grass forage which play a significant role in ruminant production in all agro-ecological zones of tropical Africa (Bamikole, 2003; Fasae et $a l ., 2010)$.These plants are relatively stable in their nutritive value throughout the year and, therefore, make important contribution to the quality of feed utilized by ruminants (Shiawoya and Tsado, 2011). The use of fodder trees, shrubs and legumes are proven to be good feed resources for ruminants and has been demonstrated as a technical solution for areas facing serious nutrient shortages (Salem and Smith, 2008).
Neem is a common tropical multipurpose evergreen tree that grows very rapidly (Mridha and Al-Suhaibani, 2014). The quality of Neem trees which are extremely resilient to challenging environment and have broad-spreading leaves, that can drop quickly in a drought so as to protect the rest of the trees makes the plant a potential feedstuff to ruminant livestock production in most tropical ecosystems where forage availability and quality decline drastically as a result of seasonal fluctuation. The different parts of neem e.g. leaf, seed, bark, flower, fruit and root are traditionally well known for its medicinal value, showing various biological activities and therapeutic potential (Brahmachari, 2004) and are utilized for variety of purposes in animal 


\section{Nutritional potentialities of neem (Azadiracthaindica) plant parts as supplementary feed}

agriculture.

Neem is regarded as a promising tree species that can be utilized in various ways to benefit agricultural communities throughout the world (Tinghuiet al., 2001). It has been described as a promising potential feed ingredient with considerable attempts made at rendering it suitable for livestock. This therefore can help in bridging the gap between supply and demands of the feeding stuff during periods of scarcity. Based on this traditional and other uses of Azadirachta indica, this study was aimed at evaluating the chemical and phytochemical constituents of Neem plant parts as supplementary feedstuff in ruminant production system.

\section{Materials and methods \\ Collection of samples}

Neem (Azadirachtaindica) plant parts were obtained from fresh undamaged matured leaves, seeds and stem bark fromand around the Federal University of Agriculture, Abeokuta, Nigeria.Samples of tenof each different neem plant partswere collected during the dry season in the month of December, 2016 and were washed to remove any traces of soil particles and other dirt, chopped in to small pieces and air dried for 15 days in shade.

\section{Chemical analyses}

The samples were ground using a hammer mill and sieved to get fine powder, bottled, labeled and analysed for proximate composition (AOAC, 2000). Crude protein content was determined by Kjeldahl method and ether extract using the Soxhlet apparatus. The fibre fractions namely neutral detergent fibre, acid detergent fibre and acid detergent lignin were determined using the methods of Van Soest et al., (1991). Quantitative phytochemical compositions including percentage composition of saponins, alkaloids, flavonoids, and tannins of the plant parts were determined as described by Harbone
(1973) and Sofowora (2008).

\section{In vitro gas production}

In vitro gas production was determined following the procedure of Menke and Steingass (1998) and the post incubation parameters evaluated following the method described by Fievezet.al (2005)

\section{Statistical analysis}

All the data obtained was subjected to oneway analysis of variance using (SAS Institute software, 1999). Statistical test was performed on level of nutritional content of both leaves, seeds and barks of neem, comparison between the level of nutritional content were done using Duncan multiple range test (Duncan, 1955).

\section{Results and discussion}

The proximate composition and fibre fractions $(\%)$ of different parts of Azadiractha indica are presented in Table 1. The DM values ranged from $88.20 \%$ in the seed to $98.00 \%$ in the leaf. The leaf had the highest $(\mathrm{P}<0.05)$ crude protein $(\mathrm{CP})$ content of $19.76 \%$ with the bark having the least value of $7.20 \%$. Neem leaf CP concentrations between $9.7 \%$ and $20.9 \%$ have been reported (Ramana et al. 2000; Bais et al., 2002; Ogbuewu et al., 2011). Variations observed across literature could be due the concentration of plant constituents which could vary from one geographical location to another depending on the age of the plant, differences in topographical factors, varietal differences, the nutrient concentrations of the soil as well as processing methods. The range of $\mathrm{CP}$ values observed across neem plant parts in this study could however enhance intake of these plant parts by ruminants as they could supply critical nutrients needed to enhance ruminal microbial growth and fermentation of feed (Raghuvansi et al., 2007). In general, all the plant parts had a CP concentration more than $7 \%$ which indicates their great nutritive value in terms of CP. Norton (1994) reported that feeds with less than $6 \% \mathrm{CP}$ levels are unlikely to 


\section{Fasae, Aganto and Jimoh}

provide the minimum ammonia levels

required for maximum microbial growth in the rumen.

Table 1: Proximate and fibre fraction composition (\%) of Azadiractha indica plant parts

\begin{tabular}{lllll}
\hline Parameters & Bark & Leaves & Seeds & SEM \\
\hline Dry matter & $96.67^{\mathrm{a}}$ & $98.00^{\mathrm{a}}$ & $88.20^{\mathrm{b}}$ & 1.83 \\
Crude protein & $7.20^{\mathrm{c}}$ & $19.76^{\mathrm{a}}$ & $13.32^{\mathrm{b}}$ & 1.21 \\
Ether extract & $4.00^{\mathrm{c}}$ & $7.33^{\mathrm{b}}$ & $9.97^{\mathrm{a}}$ & 1.19 \\
Ash & $9.67^{\mathrm{b}}$ & $11.67^{\mathrm{a}}$ & $9.33^{\mathrm{b}}$ & 0.52 \\
Neutral detergent fibre & $59.33^{\mathrm{a}}$ & $56.67^{\mathrm{b}}$ & $51.33^{\mathrm{c}}$ & 1.62 \\
Acid detergent fibre & $40.63^{\mathrm{a}}$ & $37.33^{\mathrm{b}}$ & $30.00^{\mathrm{c}}$ & 1.43 \\
Acid detergent lignin & $11.33^{\mathrm{a}}$ & $7.67^{\mathrm{b}}$ & $6.33^{\mathrm{b}}$ & 0.44 \\
\hline
\end{tabular}

${ }_{a b c}$ Means in the same row with the same superscripts are significantly different $(P<0.05)$

The ether extract (EE) values which represented the crude fat content was significantly different $(\mathrm{P}<0.05)$ among the different plant parts with Neem seeds and leaves being richer in fat compared to the bark. The EE values recorded for the different plant parts however showed that they contained adequate crude fat to satisfy the energy requirement of ruminant animals for productive purposes. Feedstuffs having crude fat value of $1-2 \%$ have been found sufficient to maintain good health by reducing risk of diseases and aging caused by its excess consumption (Sodamade, 2013).

Also, there were variations $(\mathrm{P}<0.05)$ observed in the fibre fractions composition of different parts of Neem. The bark had the highest value $(59.33 \%)$ for neutral detergent fibre (NDF) with least values in seed $(51.33 \%)$, while the acid detergent fibre (ADF) recorded the highest and lowest values of $40.63 \%$ and $30.00 \%$ for bark and seeds, respectively. Similar values for NDF and ADF levels have been reported for tropical fodder trees (Ramana et al., 2000; Kumar and Sharma, 2003).

The NDF concentration of the plant parts were below $60 \%$ which has been reported as the threshold level of NDF in tropical plants beyond which feed intake of ruminants is affected (Meissner et al., 1991). The NDF is the best indicator to predict fodder quality as it is related to the intake potential of the fodder and energy value. The low fibre content of neem, suggests it as a potential and important source of readily fermentable carbohydrates in ruminant feed. However, the high significant level of ADL in the bark in comparison to leaves and seeds is in consistent with the reports of Chaves et al. (2012) that, lignin is more present in high proportion in stem than leaves.

The phytochemical composition (\%) of different plant parts of neem are presented in Table 2. The qualitative screening revealed the presence of alkaloids, flavonoids, saponin, and tannin in all parts investigated but in varying quantities and these constituents have been found and known to have anti-protozoal and antibacterial activities (Anyanwu and Dawet, 2005).

Neem bark in comparison with the other parts of the plant had greater $(\mathrm{P}<0.05)$ percentage of these constituents closely followed by the leaves and seeds having lower percentages.

Table 2: Phytochemical composition (\%) of Azadiractha indica plant parts

\begin{tabular}{lllll}
\hline Parameters & Bark & Leaves & Seeds & SEM \\
\hline Alkaloid & $2.58^{\mathrm{a}}$ & $1.24^{\mathrm{b}}$ & $0.88^{\mathrm{c}}$ & 0.26 \\
Flavonoid & $2.23^{\mathrm{a}}$ & $0.86^{\mathrm{b}}$ & $0.22^{\mathrm{c}}$ & 0.29 \\
Tannin & $2.43^{\mathrm{a}}$ & $1.97^{\mathrm{b}}$ & $1.74^{\mathrm{c}}$ & 0.10 \\
Saponin & $2.99^{\mathrm{a}}$ & $2.15^{\mathrm{b}}$ & $1.99^{\mathrm{c}}$ & 0.16 \\
\hline
\end{tabular}

${ }^{\text {abc Means in the same row with the same superscripts are significantly different }(P<0.05)}$ 
The phytochemical properties identified in Neem have been severally reported in other plants to play important role in arresting disease pathogenesis and used traditionally as analgesic, antimicrobial and soothing herbs (Olafimihan, 2004; Ganesh and Vennila, 2011). The concentrations of these compounds in neem plant parts as observed in this study are similar to what have been reported for other ligneous fodder species and below the level that will depress feed intake in ruminants (Niranjan et al., 2008). Moreover, Azadirachtin extracts from the seeds, leaves and bark of the Neem tree has however been reported, though that was not carried out in this study. Azadirachtin have been found to possess strong biological activities against insect pests, acting as an insect repellent, inhibiting them from feeding, thus disrupting their growth, metamorphosis and reproduction, but with very low toxicity to mammals and the environment (Makeri et al., 2007).
The in vitro gas production for the different parts of Neem at different incubation periods is present in Figure 1.Gas production of plant parts increased $(\mathrm{P}<0.05)$ with increasing incubation time. The highest gas production was observed in the leaves with the bark showing the lowest gas production during all the incubation times. Meanwhile, the low gas production in bark may be related with its high fibre contents (Delgado et al. 2007). It is well documented that the nutrient contents of feeds affect their potential production of gas quantity and level of gas produced tends to decrease or increase with changing chemical content of feeds (Abdulrazak et $a l ., 2000)$. The range of values of gas produced by Neem plant parts in this study showed that the leaves and seeds are good source of fermentable substrate capable of contributing to ruminant feed resource while the bark could be regarded as roughages with little nutritional value.

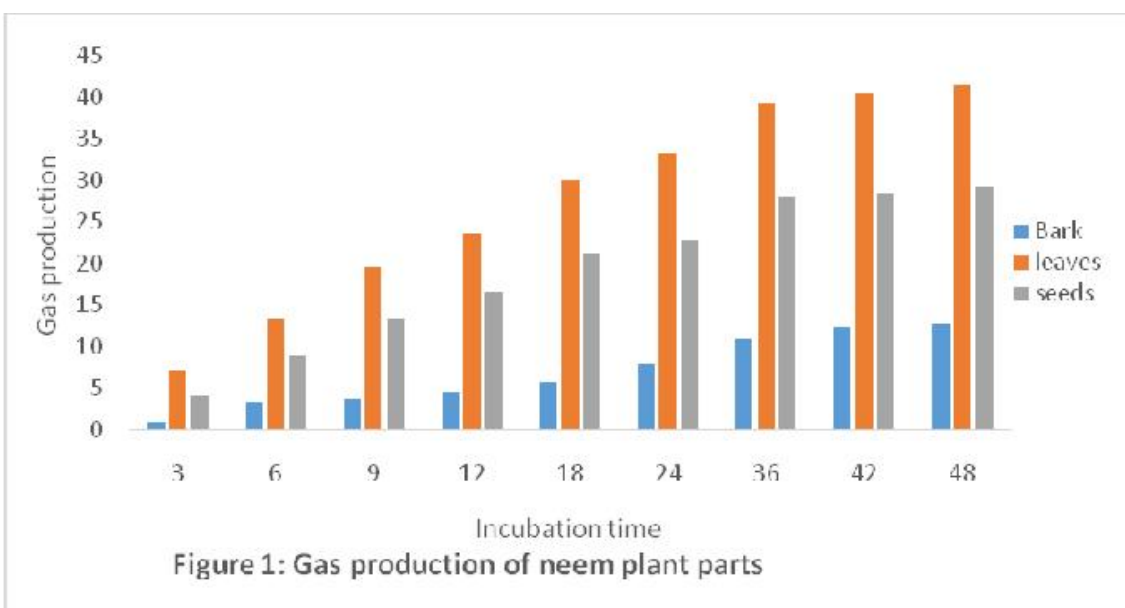

Moreover, the values obtained in the present study for in vitro gas production were slightly lower to those reported for tropical browses which could be attributable to the presence of secondary metabolites in Neem. Feedstuffs that are inherent with certain anti-nutritive factors and secondary metabolites have been reported to be affected by the amount of gas produced during fermentation, depending on the nature and level of fibre (Babayemi et al., 2004) and potency of the rumen liquor for incubation. It is possible to attain potential gas production of feedstuff if the donor animal from which rumen liquor for incubation was collected got the nutrient requirement met. Generally, gas production is a function of and a mirror of degradable carbohydrate and therefore, the amount depends on the nature of the carbohydrates 


\section{Fasae, Aganto and Jimoh}

(Blummel and Becker, 1997).

Table 3 shows the gas production kinetics and some post-incubation parameters of Azadiractha indica plant parts. In vitro Dry matter digestibility (IVDMD) differed ( $\mathrm{P}<$ $0.05)$ within neem plant parts. Methane $(\mathrm{mL} / 200 \mathrm{mgDM})$ production also differed $(\mathrm{P}<0.05)$ and ranged from 10.40 in bark to 26.00 in leaves, following the same trend as IVDMD. This finding corroborates earlier reports that feedstuffs which have higher gas production and IVDMD tend to have higher methane production per gram DM incubated (Jayanegara et al., 2011). Methane production indicates an energy loss to the ruminant and many tropical feedstuffs have been implicated to increase methanogenesis as an integrated part of carbohydrate metabolism (Demeyer and Van Nevel, 1975).

Table 3: Post incubation parameters and gas production kinetics of Azadiractha indica plant parts

\begin{tabular}{lllll}
\hline Parameters & Bark & Leaves & Seeds & SEM \\
\hline Dry Matter Digestibility (\%) & 20.00 & 28.00 & 24.00 & 1.00 \\
Methane (mL/200mgDM) & $10.40^{\mathrm{c}}$ & $23.60^{\mathrm{a}}$ & $13.60^{\mathrm{b}}$ & 1.55 \\
b (mL/200mgDM) & $14.39^{\mathrm{b}}$ & $16.12^{\mathrm{b}}$ & $37.14^{\mathrm{a}}$ & 3.28 \\
c (mL/hr) & $0.05^{\mathrm{b}}$ & $0.65^{\mathrm{a}}$ & $0.07^{\mathrm{b}}$ & 0.09 \\
Lag time(hour) & 2.80 & 1.55 & 1.92 & 0.26 \\
\hline
\end{tabular}

abc Means in the same row with the same superscripts are significantly different $(\mathbf{P}<0.05)$

b: asymptotic gas production (mL/0.5gDM); c: rate of gas production (/hour)

All the plant parts significantly affected $(\mathrm{P}<0.01)$ the gas production parameters $(\mathrm{b}$, $\mathrm{c}$ and lag time). The gas production from insoluble fraction, $b(\mathrm{~mL} / 200 \mathrm{mg} \mathrm{DM})$ was between 14.39 and 37.14 , the rate of gas production, $\mathrm{c}$ was between 0.05 and 0.65 while the lag time (hours) was between 1.55 and 2.80. Moreover, the leaves of neem induced a faster fermentation as the lag time disappeared with a higher rate of gas production, which is in consonance with earlier reports that the shorter the lag time, the faster rate of fermentation (Bueno et al., 1999; Li et al., 2015). Lag time is an indicative of the time taken for microbes to adhere themselves to the substrates, which is a pre-condition for digestion to proceed. The higher extent of gas production and rate of degradation of neem leaves in comparison with other plant parts suggests that rumen microbes were able to utilize the feed better probably due to a higher content of fermentable nutrients.

\section{Conclusion}

In conclusion, the study reveals that neem plant parts are highly digestible and contain high concentrations of crude protein and low cell wall contents that could make it a good source of nutritional supplement in the diet of ruminants thereby minimizing nutrient deficiencies faced by ruminants grazing animals especially during the rainy season. The presence of phytochemical constituents namely saponins, alkaloids, flavonoids, and tannins in these plant parts also confirm and support the traditional use of neem plant in the management of various diseases.

\section{References}

Abdulrazak, S. A., Orden, E. A., Ichinohe, T. and Fujihara, T. 2000. Chemical composition, phenolic concentration and in vitro gas production characteristics of selected acacia fruits and leaves. Asian-Aust. J. Anim. Sci., 13 (7): 935-940.

Anyanwu, G. I. and Dawet, A. 2005. $\mathrm{Ph}$ armacological and phytochemical screening of HyptissuaveolensPoit (Lamiaceae) for bioactivity in rodents. Nigerian Journal of Botany, 18: 190-196.

AOAC 2000. Association of Official 
Nutritional potentialities of neem (Azadiracthaindica) plant parts as supplementary feed

Analytical Chemists Inc. Volume 2, Washington DC,

Babayemi, O.J., Demeyer, D. and Fievez, V. 2004. In vitro rumen fermentation of tropical browse seeds in relation to their content of secondary metabolites. J. Anim. Feed Sci., 1:31-34.

Bais, B., Purohit, G. R., Dhuria, R. K. and Pannu, U. 2002. Nutritive value of sares and neem leaves in Marwari goats. Indian Journal of Animal Nutrition, 19(3): 266-268.

Bamikole, M. A. 2003. Macro-minerals bioavailability study in goats fed forages of nitrogen fertilized Guinea grass and Guinea grassVerano stylo mixture. Livestock Research for Rural Development 1

(12)http://www.lrrd.org/lrrd15/12/ bami1512.htm.

Bhowmik, S., Chowdhury, S. D., Kabir, M. H. and Ali, M. A. 2008. Chemical composition of some medicinal plant products of indigenous origin. The Bangladesh Veterinarian, 25(1):32.

Blummel, M. and Becker, K. 1997. The degradability characteristics of fifty-four roughages and roughage neutral detergent fibers as described by in vitro gas production and the relationship to voluntary feed intake. $\mathrm{Br} J$ Nutr. 77:757-768.

Brahmachari, G. 2004. Neem-An omnipotent plant: A retrospection. Chem BioChem, 5:408.

Bueno, I. C. S., Abdalla, A. I., Cabral Filho, S. L. S., Vitta, D. M., Owen, E., Mauricio, R. M., Givens, D. I., Sutton, J. D. and Mould, F. L. 1999. Comparison of inocula from sheep and cattle for the in vitro gas production technique under tropical conditions. Proc. of British
Society of Animal Science.1999, p. 151.

Chaves, A. V., Waghorn, G. C. and Tavendale, M. H. 2002. A simplified method for lignin measurement in a range of forage species. Proceedings of the New Zealand Grassland Association, 64, 129-133.

Delgado, D. C., La, O. O. and Chongo, B. 2007. Bromatological composition and in situ ruminal degradability of tropical legumes with perspectives of use in cattle productive systems. Cuban J. Agric. Sci., 41 (4): 323326.

Demeyer, D. I. and Van Nevel, C. I. 1975. Methanogenesis, an integrated part of carbohydrate fermentation and its control. In digestion and metabolism in the ruminant (L.W. McDonald and A.C.I. Warner,eds.) pp. 366-382. The University of New England Publishing Unit, Armidale, N.S.W., Australia.

Duncan D. B. 1955. Multiple range and multiple F tests. Biometrics 11:142.

Fasae, O. A., Sowande, O. S. and Popoola, A. A. 2010. Evaluation of selected leaves of tree and foliage of shrubs as fodder in ruminant production, Journal of Agricultural Science and Environment, 10 (2): 36-44.

Fievez, V., Babayemi, O. J. and Demeyer, D. 2005. Estimation of direct and indirect gas production in syringes: A tool to estimate short chain fatty acid production requiring minimal laboratory facilities.Anim. Feed Sci. and Technol., 123-124: 197210.

Ganesh, S. and Vennila, J. J. 2011. Phytochemical analysis of Acanthus ilififolius and Avicennia officinalis. Res. J. Phytochem. 
4:109-111.

Harbone, J. B. 1973. Phytochemical methods: A guide to modern technique of plant analysis. Chapman and Hall, London, 279

Irshad, Ahmad, M. I., Goel, H. C. and Rizvi, M. M. A. 2010 . Phytochemical screening and highperformance TLC analysis of some cucurbits, Res. J. Phytochem, 4: 242247.

Jayanegara, A., Wina, E., Soliva, C. R., Marquardt, S., Kreuzer, M. and Leiber, F. 2011. Dependence of forage quality and methanogenic potential of tropical plants on their phenolic fractions as determined by principal component analysis. A $n i m \quad F e e d \quad S c i$ Technol.,163:231-243.

Kumar, A. and Sharma S. D. 2003. Nutritive evaluation of some fodder tree leaves for ruminants in Tarai Region of Uttaranchal. Indian Journal of Animal Nutrition, 20(2): 161-167.

Li Wen He, Qing Xiang Meng, De Yong Li, Fei Wang and Li Ping Ren 2015. Effect of steam explosion on in vitro gas production kinetics and rumen fermentation profiles of three common straws, Italian Journal of Animal Science, 14:4, 4076.

Makeri, H. K., Maikai, V. A. and Nok, J. A. 2007. Effect of topical application of neem seed (Azadirachtaindica) extract on $\mathrm{s} \mathrm{h}$ e e p infe s t e d with Amblyommavariegatum. African Journal of Biotechnology. 6(20):2324-2327.

Meissner, H. H., Viljoen, M. O. and van Niekerk, W. A. 1991. Intake and digestibility by sheep of Antherphora, Panicum, Rhodes and Smooth finger grass. In: Proc. 4th International Rangeland Congress, September 17th-21st, Montpellier, France

Menke, K. H. and Steingass, H. 1988. Estimation of the energetic feed value obtained from chemical analysis and in vitro gas production using rumen fluid. Anim Res Dev.;28:7-55.

Mridha, M. A. U. and Al-Suhaibani, N. A. 2014. Prospect of Neem Plantation at Arafat, Saudi Arabia. Curr. World Environ.;9 ( 1). do i : http://dx.doi.org/10.12944/CWE.9. 1.12

Niranjan, P. S., Udeybir, S. J. and Verma, D. N. 2008. Mineral and antinutritional factors of common tree leaves. Indian Veterinary Journal, 85: 1067-1069.

Norton, B. W. 1994. Tree legumes as dietary supplements for ruminants. In: Gutteridge R.C., Shelton H.M. (eds):Forage tree legumes in tropical agriculture. 20th Ed. CABI International, Wallingford, UK.

Ogbuewu, I. P., Odoemenam, V. U., Obikaonu, H. O., Opara, M. N., Emenalom, O. O., Uchegbu, M. C., Okoli, I. C., Esonu, B. O. and Iloeje, M. U. 2011. The growing i m portance of ne e m (Azadirachtaindica) in agriculture, industry, medicine and environment: A review. Research Journal of Medicinal Plant, 5(3): 230-245.

Olafimihan, C.A. 2004. Effects of seasonal variation on the antibacterial activity of aqueous extract of Azadirachta indica fresh stem bark, Biosci. Res. Commun., 16: 13-16.

Raghuvansi, S. K. S., Prasad, R., Mishra, A.S., Chaturvedi, O.H., Tripathi, M. K., Misra, A. K., Saraswat, B. L. and Jakhmola, R. C. 2007. Effect of inclusion of tree leaves in 


\section{Nutritional potentialities of neem (Azadiracthaindica) plant parts as supplementary feed}

feed on nutrient utilization and rumen fermentation in sheep. Bioresource Technology, 98:511-517.

Ramana, D. B. V., Singh, S., Solanki, K. R. and Negi, A. S. 2000. Nutritive evaluation of some nitrogen and non-nitrogen fixing multipurpose tree species. Animal Feed Science and Technology, 88: 103-111.

Salem, H. B. and Smith, T. 2008. Feeding strategies to increase small ruminant production in dry environments. Small Ruminant Research.77: 174-194.

SAS, 1999. Statistical Analysis System user's guide (Version 8). SAS Institute Inc., SAS Campus Drive, Cary, N.C., USA.

Shiawoya, E. L. and Tsado, D. N. 2011. Forage and Fodder Crop Production in Nigeria,Problems and prospects. World J. Life Sci. and Medical Research;1(4):89

Sofowora, A. 1993. Medical Plants and Traditional Medicine in Africa. (2nd ed.), Spectrum Books Ltd. Ibadan, Nigeria Pp. 71-73 (289pp).
Sodamade, A., Bolaji, O. S. and Adeboye, O. O. 2013. Proximate analysis, mineral contents and functional properties of Moringa oleifera leaf protein concentrate. Journal of Applied Chemistry, 4, 47-51.

TinghuiXin, Malcolm Wegener Michael O'Shea Ma Deling 2001. World distribution and trade in neem products with reference to their potential in China.Conference of Australian Agricultural and Resource Economics Society, Adelaide, 22-25 January, 2001.

Van Soest, P. J., Robertson, J. D. and Lewis, B. A. 1991. Methods for dietary fiber, neutral detergent fiber and non-starch polysaccharide in relation to animal nutrition. $J$. Dairy Sci. 74, 3583-3597.

Received: $10^{\text {th }}$ January, 2018

Accepted: $12^{\text {th }}$ May, 2018 